\title{
模擬トリー（細管）中の放電特性と それを介したポリプロピレンフィルムの絶縁破壊
}

正員今井國治 (名城大)
学生員竹内悟 (名 城 大)
学生員山西真贵 (名城 大)
正員兼松篤 (名城大)
正員緡田正人 (名城大)

Discharge Characteristics in Simulated Treeing Channel and the Partial Discharge Induced Breakdown of the Polypropylene Film

Kuniharu Imai, Member, Satoru Takeuchi, Student Member, Masaki Nishiyama, Student Member,

Atsushi Kanematsu, Member, Masahito Nawata, Member (Meijo University)

In this paper, discharge characteristics in a simulated treeing channel have been clarified and relationship between an electric breakdown and a superstructure of PP films in a composite insulation simulated treeing channel model have been clarified on the basis of this characteristics. The following are these results.

1. The discharge voltages in a simulated treeing channel increase with channel lengths and decrease with specimen temperatures. Moreover these are higher than one in tungsten-plate electrode system.

2. In the case of a simulated treeing channel on the boundary between spherulites, the electric breakdown occurs in only boundary under DC and impulse applied voltage. In this case, properties of the electric breakdown are good according with the discharge characteristics in a simulated treeing channel.

3. In the case of a simulated treeing channel on a spherulite, the electric breakdown occurs in only spherulite under impulse applied voltage. However, for smaller specimen temperatures than $60^{\circ} \mathrm{C}$ under DC applied voltage, the degeneration area extend to the boundary is recognized, and the electric breakdown occurs in the boundary. For larger than $60^{\circ} \mathrm{C}$, many small electric breakdown points and a bigger point were recognized in the spherulite. In the case, electric breakdown voltage are higher than one given by case of a treeing channel on the boundary under various channel lengths and specimen temperatures.

キーワード 摸擬トリー、複合絶縁系模擬トリ一試料、高次構造、ホモ空間電荷

\section{1. まえがき}

ポリエチレンなどの合成高分子材料は、電気的 、機珹的 性質など総合的に優れた性能を有することから電力用プラ スチックケーブルを始めとした各種電気機器の絶縁材料と して広く使用されている。この電気絶縁層は比較的肉厚で その絶縁破壊はトリーイング現象の発生、伸展によって生 じることが知られている(1)。その中でもトリーの伸展に関 する㼋究は数多く行われており、トリーの伸展はトリ一管 路中に点弧する放電との間に強い相関があることが指摘さ れている ${ }^{(2)}$ 。このことからトリ一管路中の放電特性を明ら かにすることはトリ一伸展機構を解明する上で非常に重要 な情報を与えることになる。

また最近では高分子材料内の高次满造とトリーの伸展と の関係についても検討が行われるようになってきた ${ }^{(3)(4)}$ 。 しかしこれらの多くはトリ一倗棂の状海を観察したものが 多く、トリ一管路中の放電特性と空間電荷及びトリ一伸展 との関係についてはあまり㭘討が行われていない。
筆者らはトリ一管路中の放電特性を検討するために、ポ リエチレンブロック内に微細な細管を作成することによっ てトリ一を模擬し、その放電特性を模擬トリーの長さ及び 試料温度をパラメータとして測定した。さらに、トリーが その先端部或いは側壁部分の固体絶縁物を破壊して伸展す ることから、模擬トリ一試料とポリプロピレンフィルムを 直列に固着させた複合系試料を作成し、模擬トリ一内で点 弧した放電によるポリプロピレンフィルムの絶縁破壊電生 を模擬トリ一の長さ及び試料温度をパラメータとして測定 した。本論文はこれらの結果をまとめたものであり、模擬 トリー内の放電点弧によって生じるポリプロピレンフィル ムの絶縁破壊の強さを概算している。また、放電点弧の位 置が球晶と球晶界面など高次構造によって絶縁破壊の強さ はどのように異なるかについても検討を行い、この結果か らトリーの伸展に必要な電界の大きさを考察している。

\section{2. 試料及び赛験方法}




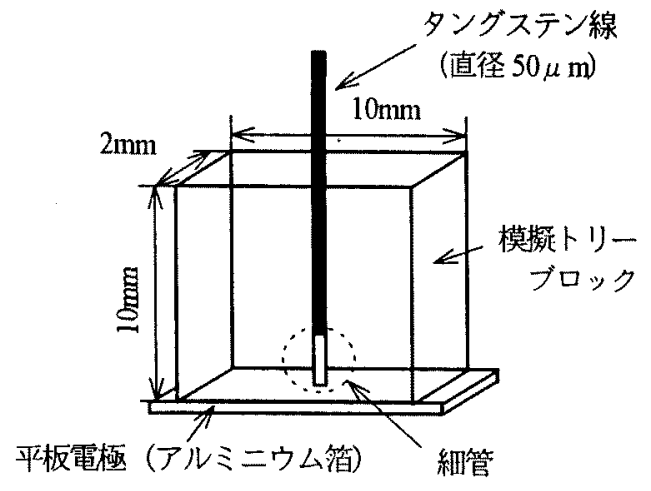

図 1 模擬卜リ一試料の形状

Fig.1. Simulated treeing channel model

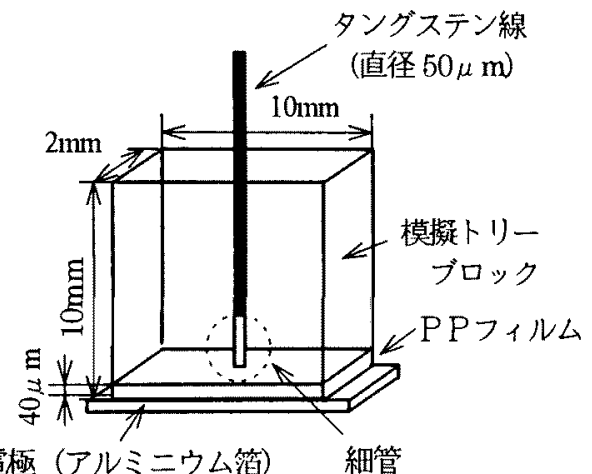

図 2 複合絶縁系模擬卜リ一試料の形状

Fig. 2. Composite insulation simulated treeing channel model

\section{<2. $1>$ 実験試料}

<2. 1. 1 > 模擬卜リ一試料

まず、 $10 \times 10 \times 1 \mathrm{~mm}$ の板状ポリエチレンを 2 枚準備し、 その間に直径 $50 \mu \mathrm{m}$ のタングステン線をはさみ、桓温槽中 でホットプレス $\left(150^{\circ} \mathrm{C} 、 15\right.$ 分間) した後、大気中にて室温 まで自然冷却した。次にマイクロメータを用いてタングステ ン線を途中まで引き抜き、細管長 1 7 mmの模擬トリーブ ロックを作成した。そして、このブロックをアルミニウム 筞平板電極の上にのせ模擬卜リ一試料（図 1) とした。そ の際模擬トリー（以後、細管と乎ぶ。）内の気密性を保つ ため、模擬トリーブロックとタングステン線及びアルミニ ウム箔電極とをエポキシ樹脂でモールドした。

\section{<2. 1. 2> 複合絶緑系模擬卜リ一試料}

厚さ $40 \mu \mathrm{m}$ のポリプロピレンフィルム(以後 P P フィル 么と呼ぶ。)を加熱処理し、直径 $300 \mu \mathrm{m}$ の球晶を成長させ た。次に模擬トリーブロックとアルミニウム管平板電極と の間に球晶成長させたPPフィルムをはさみ複合絶縁系模 擬トリ一斌料（図2）を作成した。この試料についても細 管内の気密性を保つため模擬トリーブロックとタングステ ン線及びアルミニウム筞平板電極をエポキシ樹脂でモール

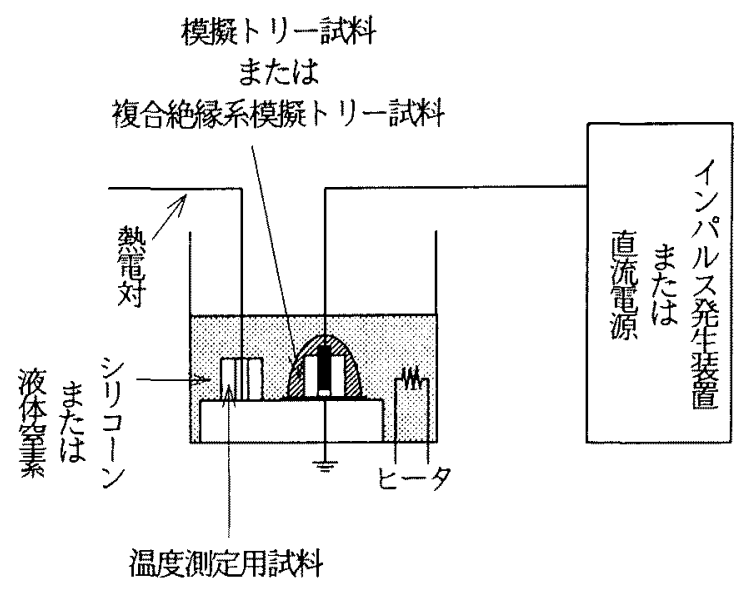

図 3 実験装置

Fig.3. Experimental equipment

ドした。

\section{<2. 2> 実験方法}

実験装置を図3に示す。試料温度の制御と沿面放電発生 防止を兼好て、試料はシリコーン油または液体空素中に浸 した。また試料温度は試料と並列に打いた温度モ二タ一用 試料によって測定した。このように設置された試料のタン グステン線電極に正、負極性の直流電圧(昇圧速度：400 $\mathrm{V} / \mathrm{sec}$ ）またはインパルス電圧（印加電圧波形：1/40 $\mu \mathrm{sec}$ ) を印加して実験を行った。この場合試料周辺の媒質は試料温 度が $0^{\circ} \mathrm{C} \sim 100^{\circ} \mathrm{C}$ まではシリコーン油を、またー $197^{\circ} \mathrm{C} \sim 0^{\circ} \mathrm{C}$ までは液体窒素を使用し、試料温度を間接的に調整した。 模擬卜リ一試料の絶縁破壊は本質的に細管内の放電による 全路破壊であり、複合絶縁系模㩲卜リ一試料の絶緣破壊は放 電を介したPPフィルムの絶䋎破壊である。このことから 本論文では模擬卜リ一試料の破壊電圧を放電電圧と呼び、 複合絶縁系模㩯卜リ一試料の破壊電圧を絶縁破壊電圧と呼 ぶことにする。

\section{3. 模擬トリ一試料の放電特性}

一般にトリ一内の放電とトリ一の伸展との間には強い相 関性があることが知られている。しかし、トリ一内の放電 がトリ一伸展にどのように関与しているかは十分に明らか にされていない。従ってトリ一細管内の放電特性を明らか にすることはトリ一伸展の機構を解明する上で非常に重要 である。従って、模擬卜リ一試料を用いて細管内の基本的 な放電特性について検討を行った。

\section{<3. $1>$ 実験秸果}

<3. 1. 1 > 模疑トリ一試料における放電電圧と 細管長との関係

図 4 は細管の放電電圧と細管長の関係を試料温度 $20^{\circ} \mathrm{C} て ゙$ 求めたものである。同図（a）は直流電圧を印加した場合 の結果であり、同図（b）はインパルス電圧を印加した場 


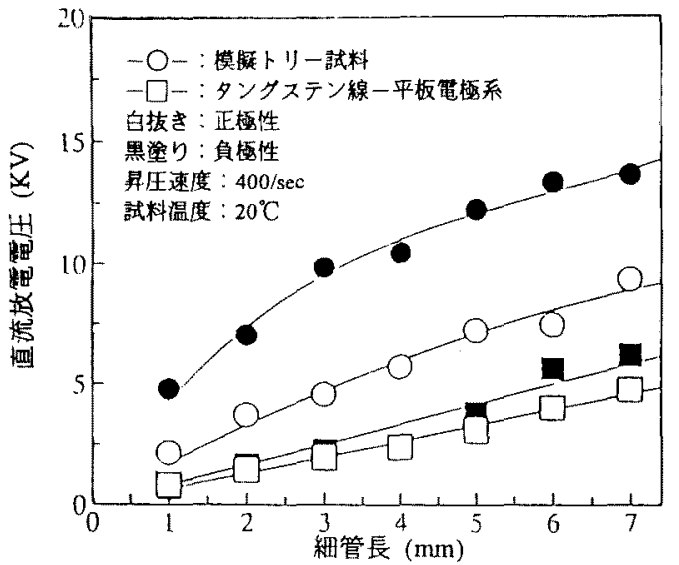

(a) 直流電圧

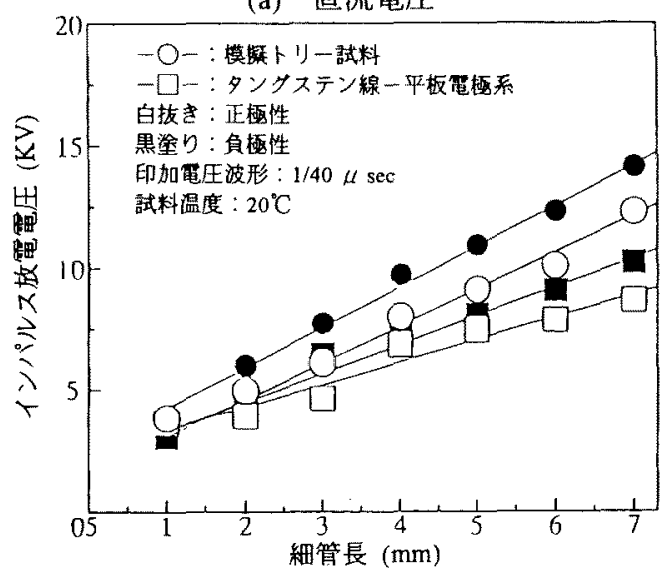

(b) インパルス電圧

図 4 模拨卜リ一試料における細管長と放電電圧との関係 Fig 4 Relation between channel length and discharge voltage for $c$ simulated treeing channel model

合の結果である。雨図とも図中の白抜き印は正極性電圧を 印加した場合であり、黒塗り印は負極性電压を印加した場 合である。また比較のため空気中 $20^{\circ} \mathrm{Cにおけるタングステ}$ ン線一平板電極系を用いた空気中の放電電生の結果も同図 に含めている。これらの図より細管の放電電生は細管長と 共に上昇し、常に負極性の場合が正極性の場合よりも高く なっている。また細管の放電電圧は空気中におけるタング ステン線ー平板電極系の放電電纴よりも高くなっている。

\section{<3. 1．2> 模擬トリ一試料における放電電圧の 温度依存性}

模擬卜リ一試料（細管長 $2 \mathrm{~mm}$ ）における直流放電電圧及 びインパルス放電電压の温度依存性を図 5 に示す。同図 （a）は直流放電電圧の温度依存性を示している。この図 に示すように直流放電電王の温度特性は極性によって異な るが、大さく3つの領域によって構成されており、これら を低温側から領域 I、領域I、領域四と呼ぶことにする。 この図より領域Iにおける液体窒素温度では極性に関係な く放電電生はほぼ一致しているが、温度上昇と共に放電電 正は徐々に低下して行き、その傾向は正極性の力が真極性 よりも大きい。領域】に扮いては試料温度に対し急激に低 下していき、極性効果は一層顕著になっている。領域回に

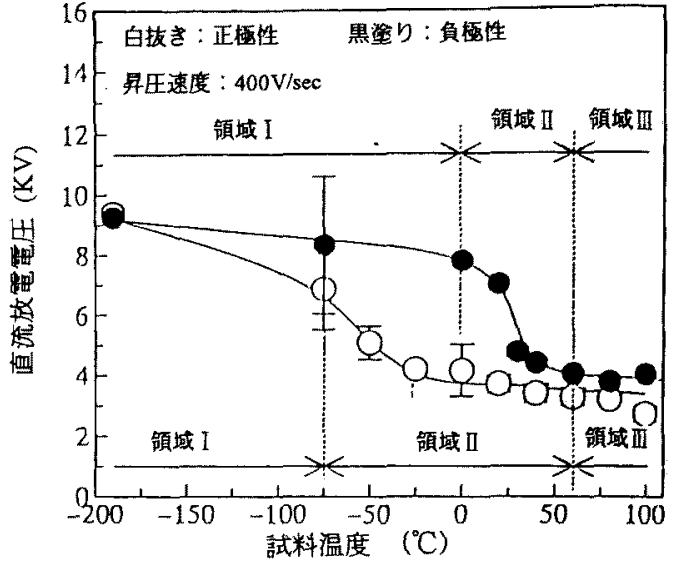

(a) 直流電圧

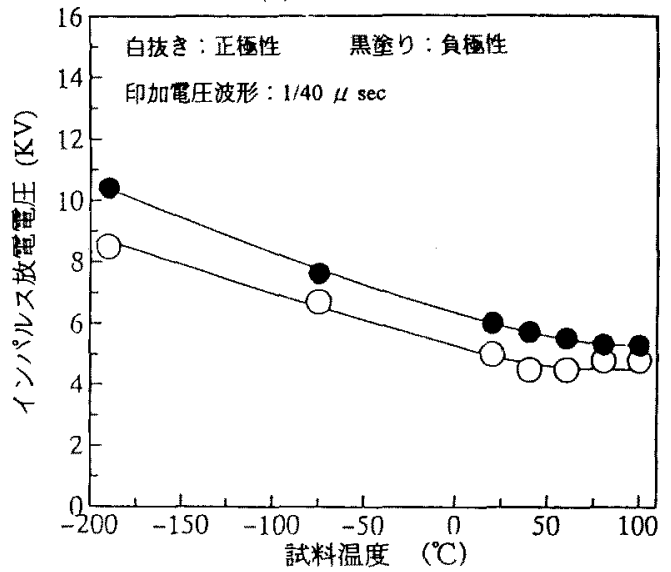

(b) インパルス電压

図 5 模擬トリ一試料における放電電圧の温度依存性 Fig. 5 Temperature dependence of discharge voltagefor a simulated treeing channel model

抒ける放電電圧は極性及び温度に関係なくほぼ一定である。

一方、同図（b）に示すように、インパルス放電電压の 場合も極性効果を示すが両極性とも試料温度の上昇に対し 単調に低下していくことがわかる。

\section{$<3,2>$ 考察}

模擬卜リ一試料における実験の結果をもとに、考察を行 $\supset$ た。

一般に細管内の放電は、空気中のタングステン線一平板 電極系における空気中の放電とは細管壁面の影響があると いう点で大きく異なると思われる。図4において、模擬卜 リ一試料の放電電仼が空気中のタングステン線一平板電極 系の放電電压よりも高い原因は、細管壁面にトラップされた ホモ空間電荷効果によると考えられる。つまり、細管直径 が $100 \mu \mathrm{m}$ になると、電子なだれの先端部分が細管の直径 よりも大きくなるという長尾氏らの報告 ${ }^{(5)}$ から、負極珄 においては細管内で発生した電子なだれの先端部分が細管 壁面内部にトラップされる。これに対して正極性の場合に おいては陽イオンが壁面に堆積し、これらがホモ空間電荷 として作用し、タングステン線付近の電界を緩和したためと 考えられる。

また、図 5 において試料温度の上昇と共に細管内の放電電 
模擬トリー（細管）中の放電特性

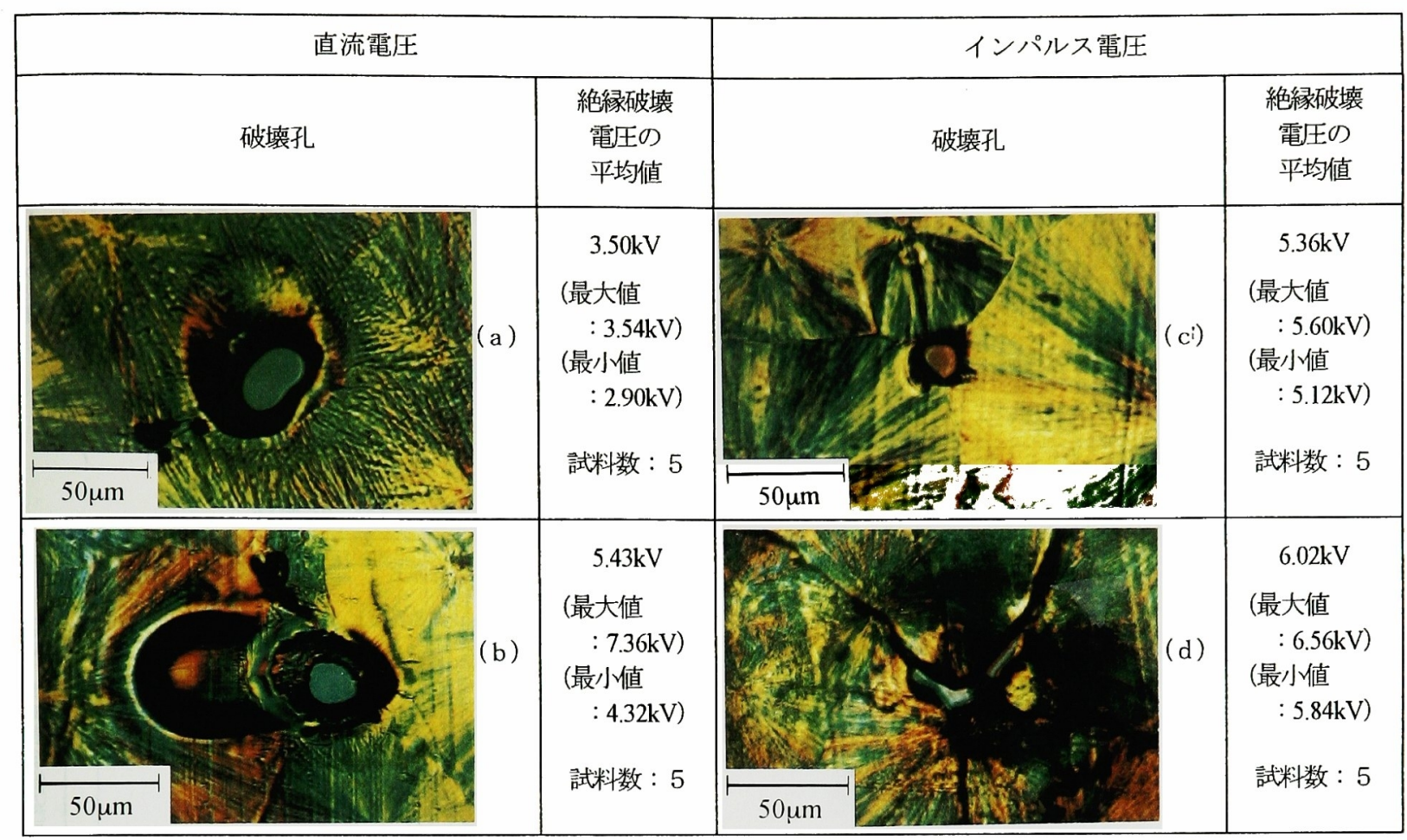

※表示したものはすべて印加電圧が正極性の場合である。

図 6 複合絶縁采模擬トリ一試料におけるP Pフィルムの破壊状況

Fig.6. Breakdown damage pattern of a PP film in a composite insulation simulated treeing channel model

玨が低下する理由として、温度上昇に伴うホモ空間電荷の 移動度の上昇が考えられる。つまり、細管壁面にトラップ されたホモ空間電荷の移動度の上昇により、平板電極側へ の空間電荷の移動が容易となり、タングステン線電極付近の ホモ空間電荷効果が小さくなる。また、印加電圧波形の違 いによる放電電压の減少傾向の相違は、細管壁面のホモ空 間電荷の形成及び移動度の変化による空間電荷の消滅の仕 方が異なっていることによると考えられる。

以上の考察より、細管の放電特性は細管壁面にトラップさ れたホモ空間電荷の様子とその効果が大きく反映している ものと考えられる。

\section{4. 複合絶緣系模擬トリ一試料における絶縁破壊特性}

前述の放電特性をもとにP P ィルムの高次構造と絶縁 破壊について実験を行い、実験結果を示すと共にP Pフィ ルムの絶縁破壊強度を概算し、トリーの伸展について考察 を行った。

\section{<4. $1>$ 実験結果}

<4. 1.1 1 > PPフィルムの絶縁破壊状況

図6は多数の複合絶縁系模擬トリ一試料を $20^{\circ} \mathrm{C}$ において 絶縁破壊させた洔のP P フルムの破壊痕跡をまとめたも のである。直流、インパルス共に2種類の破壊痕跡が観察 された。即ち、直流電圧印加の場合には、同図（a）のよ うに球晶界面部分に破壊孔がある場合と、（b）のように、 破壊孔は球晶界面にあるが、球晶上に放電によって溶解さ れたと思われる痕跡を伴っている場合である。一方、イン パルス電圧印加の場合には、破壊孔が球晶界面部分にある 場合（c）と球晶部分にある場合（d）である。また、こ れらの破壊痕跡に対応した絶縁破壊電圧を比較すると、

（b）は（a）より $1.93 \mathrm{kV} 、 \quad$ (d) は（c）より $0.66 \mathrm{kV}$ 高くなっている。P Pフィルムを模擬トリーブロックに固 着させて、複合絶縁系模擬トリ一試料を作製する際、模擬 トリー細管直下がP Pフィルムの球晶部分となるか、また は球晶界面部分となるかは定かではない。しかし、破壊状 況及び、絶縁破壊電圧の大ささの差、また、球晶の絶縁破 壊電压が球晶界面のそれより高いという報告 ${ }^{(7)}$ を考慮する と、（a）、（c）の場合は細管直下に球晶界面部分が、 また（b）、（d）は球晶部分が固定されたと推定できる。 次に述べる「球晶の絶縁破壊電圧」と、「球晶界面の絶 縁破壊電圧」という破壊電圧の分類は、この破壊状況の観 察にもとづいて行っている。

\section{<4. 1. 2> 複合絶縁系模擬トリ一試料における 絶縁破壊電圧と細管長との関係}

ここでは細管の固定位置をパラメータとして複合絶縁系 模擬トリ一試料の絶縁破壊電圧と細管長との関係を求めた。 図7は直流電压、図8はインパルス電圧を印加した時の結 


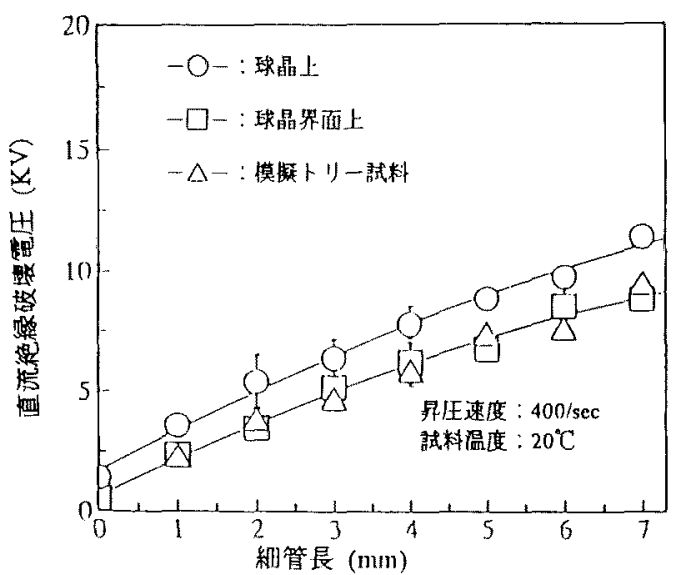

(a) 正極性

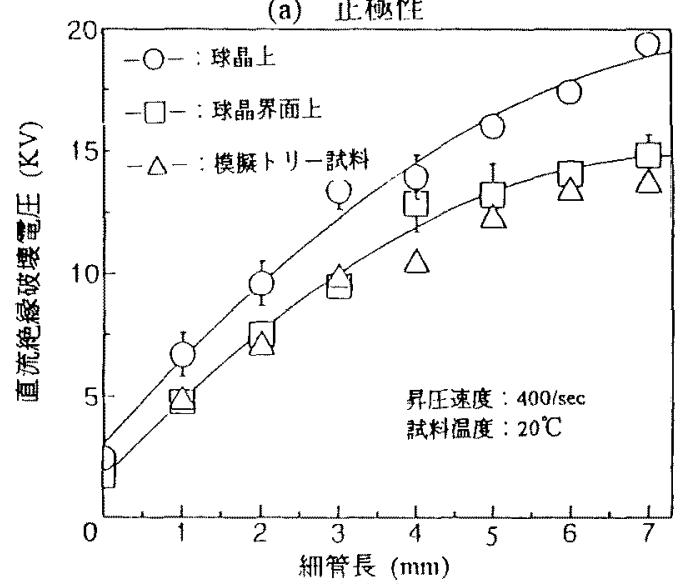

(b) 争極性

图 7 復合絶縁系模擬卜リ一試料における 細管長と直流䋓縁破壊電玨との関係

Fig.7. Relation between channel length and DC electric breakdown voltage for a composite insulation simulated treeing channel model

果を示している。雨図とも（a）は正極性電在在印加した 場合であり、（b）は負極性電王を印加した場合である。 また比較のため模擬卜リ一試料における放電電压の特性（図 4）も同図に含めている。これらの図より、細管の固定位 置及び印加電压の波形、極性に関係なく、䍃緣破壊電生は 絒管長が長くなるに钕って高くなる㑯向を示している。ま た球晶界面の總䋎破壊電压は模擬卜リ一試料の放電電在之 ほぼ一致している。これに対し、球晶の絈縁破壊電压は模 捙トリー試料の放電電压よりも高くなっている。さらに直 流電左印加の場合には、その差は細管長が長くなるに徒っ て大きくなる傾问にあるが、インタ゚ルス電王印加時には細 管長に甪係なく、ほぼ一定である。

\section{<4. 1. 3> 複合絶緑系模擬トリ一試料における 絶縁破壊電圧の温度依存性}

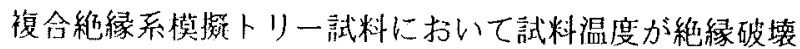
雷日にどのような影響を与えるかを検討するため細管長一

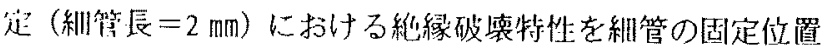
をパラメータとして求めた。

図9は直流電压、因10はインパルス電王を印加した時

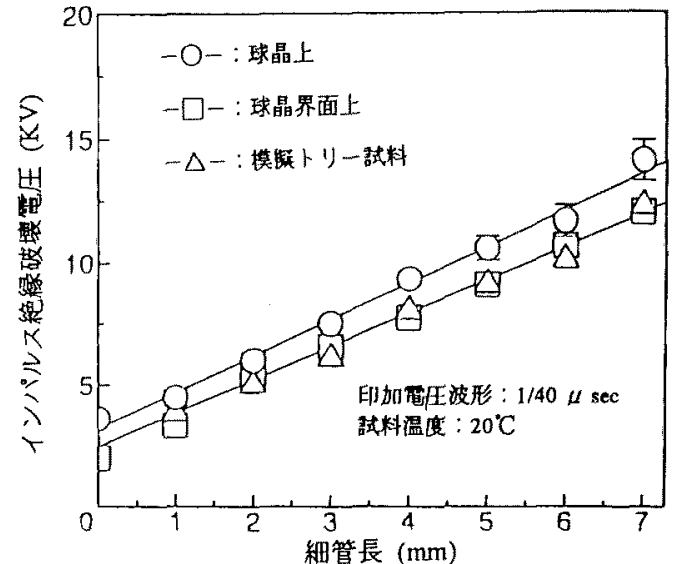

(a) 正極性

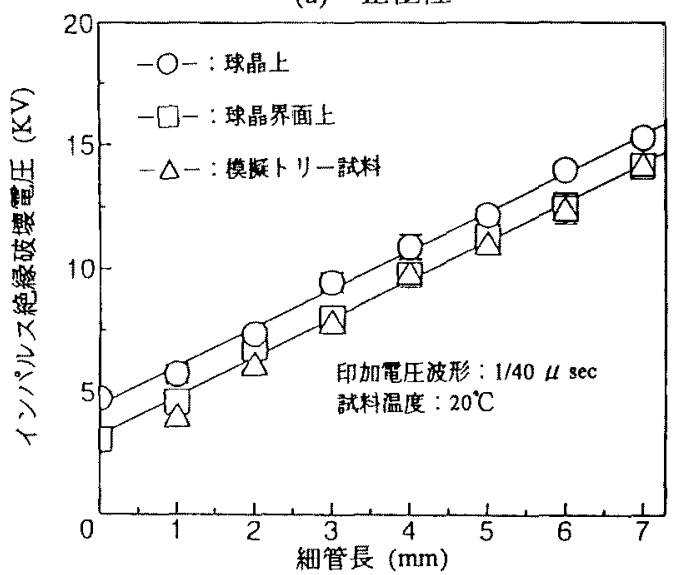

(b) 負極性

図 8 複合絶縁系模擬卜リ一試料における 紐管長とインパルス純縁破壊電圧との関係 Fig. 8. Relation between channel length and Impulse electric breakdown voltage for a composite insulation simulated treeing channel model

の結果を示している。两図とも（a）は正極性電在を、（ b）は負極性電王を印加した場合である。これについても 比較のため模擬卜リ一試料における放電電压の温度依存性 (図5)在同図に含めている。

図9の直流紿縁破壞電压の特徽は次のようにまとめられ る。（1）：模擬トリ一試料に打ける放電電压の温度低存性 と同様に3つの温度領域に分かれる。(2)：球晶界面の絶 縁破壊電王はどの領域においても模擬卜リ一試料における 放電電压とほほ一致する。一力、(3)：球晶の總緣破壇電 圧は領域 I 及び領域 II では模擬卜リ一試料の放電電生と同 傾向の変化を示すが、その值は放電電圧よりも䯩くなる。 しかし、（4）: 領域且では図 11 のような球晶全体が变質 (同図（a））し，多数の微小孔（同図（b））もしくは くぼんだ部分（同図（c））と思われる破壊痕跡が新たに出

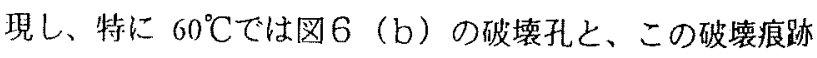
が混在して钼察されるようになる。これに対応して、図 9

(a)、（b）の右上に示した拡大図からもわかるように、

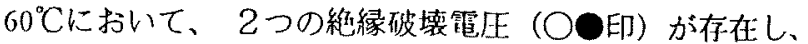
それ以上の温度では、その低い万の約縁破壊電㽵（O印） と一致している。しかし雨破壊電生とも細管の放電笔压よ 


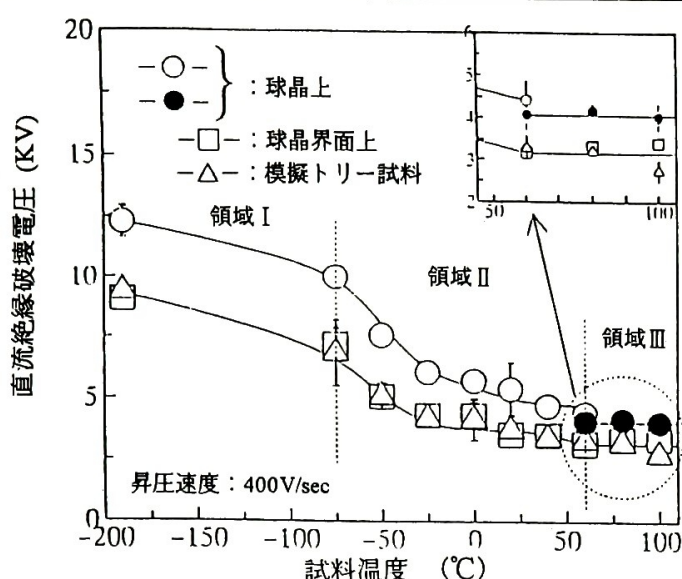

(a) 正極性

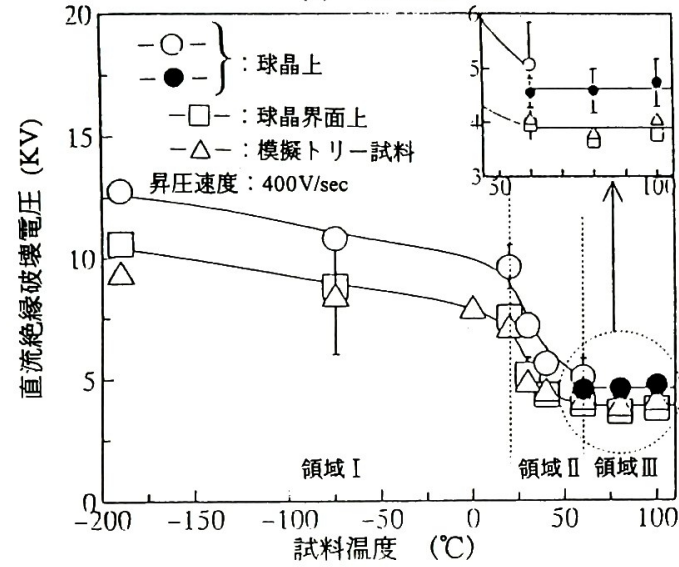

(b) 負極性

図 9 複合絶縁系模擬トリ一試料における 直流絶縁破壊電压の温度依存性

Fig.9. Temperature dependence of DC electric breakdown voltage for a composite insulation simulated treeing channel model

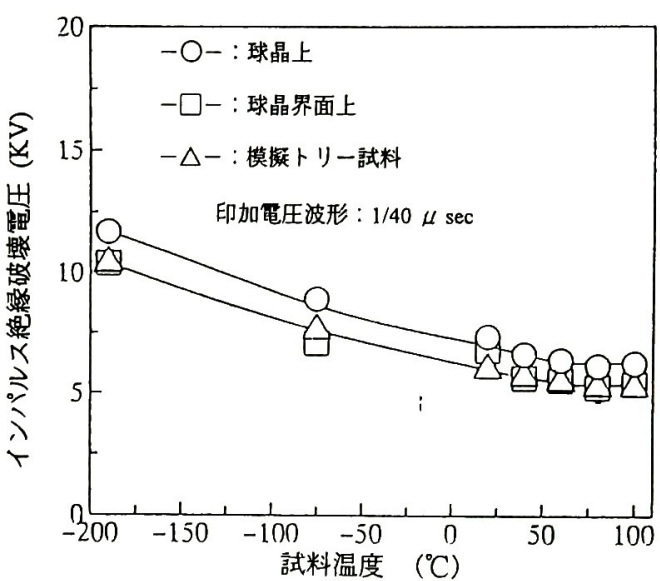

(a) 正極性

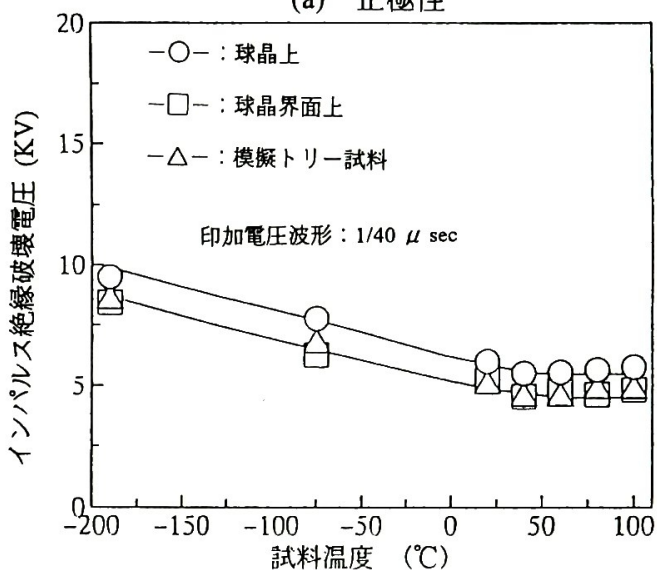

(b) 負極性

図 10 複合絶縁系模擬卜リ一試料における

インパルス絶縁破壊電圧の温度依存性

Fig. 10. Temperature dependence of Impulse electric breakdown voltage for a composite insulation simulated treeing channel model

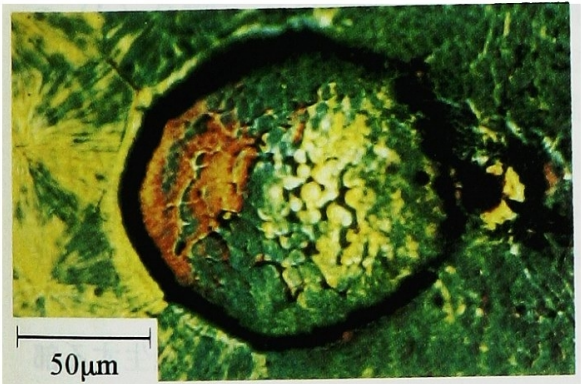

（a）顕微鏡写真

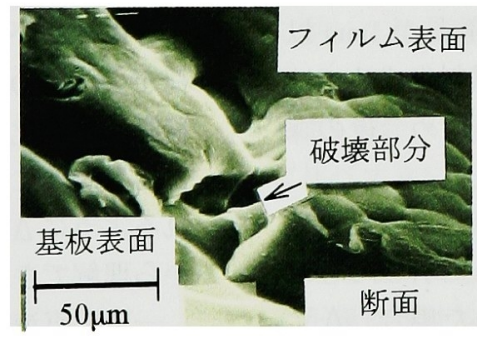

（b）破壊部分の SEM 像

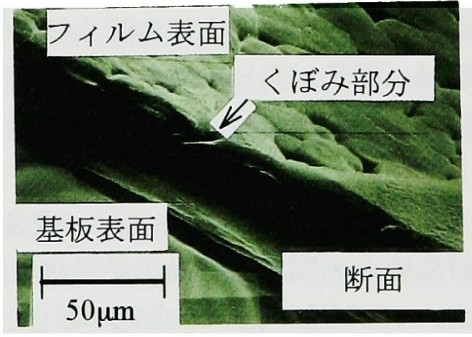

（c）くぼみ部分のS EM像

図 11 試料温度 $80^{\circ} \mathrm{C}$ における球晶の破壊状況 Fig. 11. Breakdown damage pattern of a spherulite at $80^{\circ} \mathrm{C}$

り高い絶縁破壊電圧を示している。

図10のインパルス電圧を印扣した場合には、球晶界面 及び球晶の絶縁破壊電压は模擬卜リ一試料の放電電圧の温 度依存性と同様に試料温度に対し単調に減少しているが、 球品界而の總縁破壊雪生は模㨡卜リ一試料の放電電王とほ ぼ一致しているのに対して、球晶の絶縁破壊電圧は模擬卜 リー試料の放電電圧よりも高くなっている。
<. $2>$ 考察

<4. 2. 1. > P P ィルムの球晶及び球晶界面 の絶縁破壊機構

複合絶縁系模擬トリ一試料の絶縁破壞は、細管内の放電 を介してPPフィルムの絇縁破壊が起こるため、P Pフィ ルムの絶縁破壊機構と細管内の放電特性を考慮する必要が ある。細管の放電特性はく3，2>で論じたように、細管 


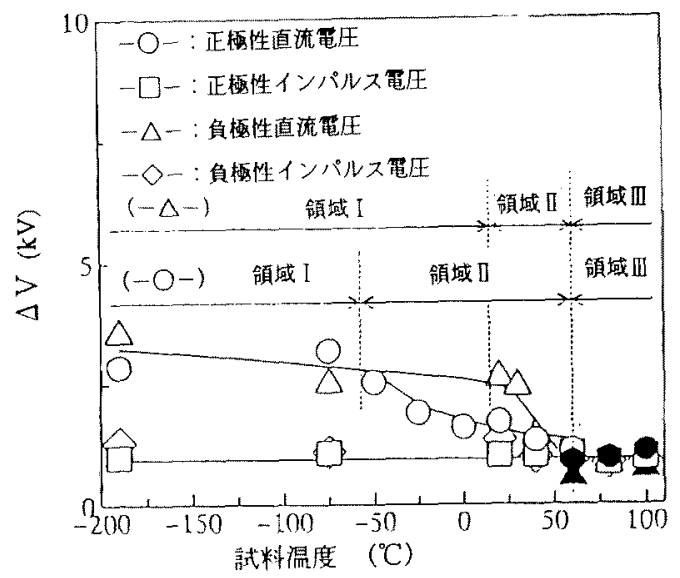

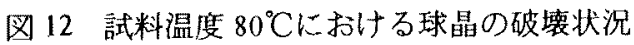

Fig. 12. Breakdown damage pattern of a spherulite at $80^{\circ} \mathrm{C}$

壁面にトラップされたホモ空間電荷の影響を受けていると 考えられるので、PPフィルム自体の絶縁破壞を考える場 合、この木モ空間電荷効果除いて考える必要がある。そ こで、複合紿緣系模擬トリ一試料の絶縁破壊電生 $V$ BD と細 管の放電電圧 $\mathrm{V}_{\mathrm{s}}$ との差 $\Delta \mathrm{V}=\mathrm{V}_{\mathrm{BD}}-\mathrm{V}_{\mathrm{s}}$ を考元、この $\Delta \mathrm{V}$ ををとにPPフィルムの絶縁破壊機構について検討した。

複合䋓縁系模擬卜リ一試料における球晶界面の䋓縁破壊 電生は模擬トリ一試料の放電電任とほぼ一致している(図7 一図10）ので、 $\Delta V=0$ である。これは細管内で放電が 発生すると、その放電電圧に相当する電荷が球晶界面上に 供給され、その電荷が作る電界が球晶界面の䋓縁破壊强度 よりも高いためにPPフィルムの絶縁破壊が起こると考え られる。即ち、細管の放電特性が球晶界面の絶縁破壊特性 を律則していることになる。この点を検討するためには、 細管の放電電圧が球晶界面の絶縁破壊電圧よりも低くなる ような条件を選ぶ必要がある。しかし細管の放電電圧が球 晶界面の紨緣破壊電生よりも低くなるのは細管長が $1 \mathrm{~mm}$ 以 下の領域（図7、図8）であり、現段階の試料作成法では この領域の試料を作成することは团難であるため今後の課 題としたい。

一方、図 12 は温度特性より（四 9、10) 求めた $\Delta V$ と試料温度との関係を球晶の絶縁破壊について示したもの である。この図よりインパルス電压を印加した場合、 $\Delta \mathrm{V}$ は試料温度に関係なくほぼ一定（正、負とも約 $1.0 \mathrm{kV}$ ) とな っている。こ机に対し直流電圧を印加した場合、因10の 領域Ｉに対応する部分では $\Delta V$ が試料温度と共に徐々に低 下していくが、領域】に対応する部分では試料温度と共に 急激に低下している。また、領域四に対応する部分では試 料温度に関係なくほぼ一定の值となり、その值はインパル スの場合とほぼ一致している。また図 13 は細管長特性（ 因7、8）上り求奴 $\Delta V$ と細管長の関係を球晶の䋓縁破 盍について示したものである。インパルス電生印加恃には図 12 と同様紐管長に関係なくほぼ一定となっている。また直 流電玨印加将には細管長と共に $\Delta V$ は増加し、その增加率

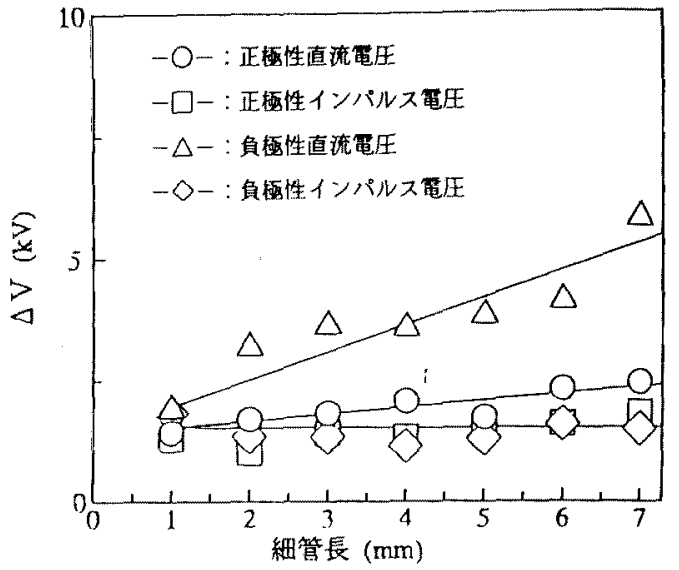

图 13 細管が球晶上にある場合の $\Delta V$ の温度依存性 Fig. 12. Temperature dependence of $\Delta \mathrm{V}$ in the case of a simulated treeing channel on a spherulite

は負極性の方が正極性よりも大きくなっている。

一般に高分子材料の絶縁破壊を考えた場合、直流䋓縁破壊 電圧がインパルス絶縁破壊電圧より高くなるのは、バルク内 への電荷注入量による空間電荷効果の差によるものと思 れる。 $\Delta \mathrm{V}$ れPフィルムの絶縁破壊電生と関連する量と 考えれば、図 12 20Vの温度依存性は同様の傾向を示し ていると見ることができる。また複合絶縁系模擬トリ一試 料に淔流電圧を印加した時、絶縁破壊が起こる直前に細管 内での発光と、印加電圧波形のパルス的な变化を伴う部分 放電が $1 〜 2$ 回必ず発生するのに対し、インパルス電化印 加時にはそのような現象はみられなかった。

インパルス電圧を印加した場合、一般に空間電荷効果は 小さいと言われており、さらに絶縁破壊直前に部分放電が 発生しないことから球晶上に蓄積された空間電荷量は少な いものと思われる。従って、この状況で細管内で放電が発 生すると、一瞬に球晶上に電荷が供給され、図6（d）の ように球晶が破壊される。また、球晶上に蓄積した空間電 荷が少ないので、試料温度の変化に伴って木モ空間電荷の 移動度が変化してもこの影響はほとんど現れず、っVはは とんど温度に依存しないことになる。また、図13に見ら れるように $\Delta \mathrm{V}$ 莯細管長によらず一定であることもこの点 から理解できる。

一方、直流電圧を印加した場合、破壊直前に発生する部 分放電によって球晶上に形成された空間電荷が木モ空間電 荷として作用し、絶縁破壊電圧值を増大させ、細管内で発 生した放電による細管直下の球晶の破壊を妨げることにな る。そのため領域 I 及びIでは図6（b）に示すように放 電は球晶ラメラに沿って沿面放電し、弱点部分である球晶 界面で破壊する。しかし、試料温度の上昇に伴って球晶上 に蓄積したホモ空間電荷の移動度が增大すると、この效果 が小さくなり、放電の直進を妨げないくらいにこの效果が 小さくなる（領域回）と、図 12 の $\Delta \mathrm{VWインパルスの \Delta}$ $\mathrm{V}$ とほぼ等しくなり、破壊状況は図11（a）の上うに図 6 (d) のインパルスの場合とは若干異なるが、球晶部分 
で破壊が起こると考えられる。この領域に対応して図 11 のような破壊状沉が出現する理由としては、熱的破壊或い はヤング率の低下に伴う䉓気機械的破堙が考えられるが、 現在のところその機桙は明らかでない。また、図13に示 すように $\Delta \mathrm{V}$ が細管長と共に大きくなることは、細管長と 罠に放電電珃が大きくなることを示すことから、これに対 沁してより大きな空間電荷が球晶上に形成されると考えれ ば䧉解できる。また直流電压の㥛性の遠い（図 $12 、 13$ ) による $\Delta \mathrm{V}$ の相違、球晶上の㕵間電荷の形成及び消滅は極性 により異なることも考えられるが、本研究の結果だけで考 察することには問題がある。

\section{<4. 2. 2> トリ一伸展電界}

本節では、細管長と絶縁破壊電圧との結果をもとにトリ 一伸展電界について検討する。

今、複合絶縁系模擬トリー試料に電圧 $V_{\mathrm{BD}}$ を印加した洔、 图14のように細管内の放電により、 $\mathrm{V}_{\mathrm{BD}}$ に相当する䨍荷 がフィルム表面に供給され、PPフィルムが䋓縁破壊した

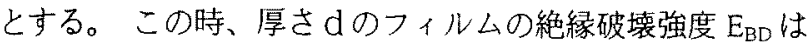
(1)式で表される。

$$
E_{B D}=\frac{2 V_{B D}}{r \ln \left(1+\frac{4 d}{r}\right)} \cdots . . . . .(1)
$$

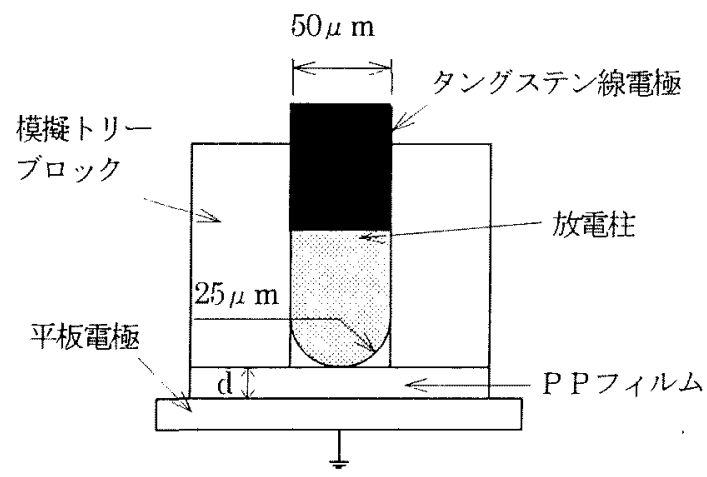

図 14 解析用モデル

Fig. 14. Analysis model

ただし、、は放電先端部分の半径である。

トリ一管路内で発生した放電によりトリ一先端部分の電 界が強められ、こ机が固体絶縁体の破壊強度に達したとさ、 トリーが伸展する(10)といわれていることを考慮すると、(1) 式の絶縁破壊強度はトリ一の伸展電界を意味している。前 述のように細管壁面や球晶上に蓄積された木モ空間電荷は 紿緣破壊電压 $V_{\mathrm{BD}}$ を上昇させるように作用している。そこ で、测定結果の中で最も空間電荷效果を含んでいない細管 長 1.0 mmにおける $V_{B D}$ を触い、枚電先端部分の半径 $\mathrm{r}$ を夕 ングステン線の半径 $(25 \mu \mathrm{m})$ に等しいと仮定して、トリ
表 1 球晶及ひ球晶界面の絶縁破壞強度

Table.1. Breakdown strength of the spherulite and its boundary

\begin{tabular}{|c|c|c|c|c|c|}
\hline & & \multicolumn{4}{|c|}{ ※単位は MV/cm } \\
\hline & & \multicolumn{2}{|c|}{ 本研究 } & \multicolumn{2}{|c|}{ 報告值 } \\
\hline & & 正極性 & 負極性 & 正極性 & 傎極性 \\
\hline \multirow{2}{*}{ 球晶 } & $\begin{array}{l}\text { 直流絶縁 } \\
\text { 破壊強度 }\end{array}$ & 1.44 & 2.67 & $2.10^{(8)}$ & - \\
\hline & $\begin{array}{l}\text { インパルス } \\
\text { 絶縁破壊強度 }\end{array}$ & 1.79 & 2.29 & $1.70^{(9)}$ & - \\
\hline \multirow{2}{*}{$\begin{array}{l}\text { 球晶 } \\
\text { 界面 }\end{array}$} & $\begin{array}{l}\text { 直流絶縁 } \\
\text { 破壊強度 }\end{array}$ & 0.96 & 1.91 & $1.15^{(8)}$ & $1.45^{(8)}$ \\
\hline & $\begin{array}{l}\text { インパルス } \\
\text { 絶縁破壇強度 }\end{array}$ & 1.34 & 1.84 & - & - \\
\hline
\end{tabular}

※報告值については論文中の図から読みとった。

一伸展電界 $\mathrm{E}_{\mathrm{BD}}$ を求めた。その結果を表 1 に示す。比校の ためこれまでに報告された平等電界中における球晶及び球 晶界面の絶縁破壊強度 ${ }^{(8)(9)}$ 向同表に含めている。

この表からわかるように、インパルス電压印加時の球晶 の $\mathrm{E}_{\mathrm{BD}}$ と報告值とはほぼ一致している。これは、インパル 又電在印加時のトリ一伸展電界が球晶の破壊電界とほぼ一 致することを示している。一方、直流電圧印加時の球晶界 面の $\mathrm{E}_{\mathrm{BD}}$ は報告值よりも若干低くなっている。これは、直 流電圧印加時の球晶界面のトリ一伸展電界が、球晶界面の絶 縁破壊電界よりも低くなることを示しており、この原因と しては放電による熱的要团が加わっているためと考えられ る。また、球晶の正の $\mathrm{E}_{\mathrm{BD}}$ は球晶界面と同様、報告値よ

りも低くなっている。これは熱的要因が加わっていること に加えて、破壊経路が図6（b）に示すように球晶ラメラ に沿って沿面放電し、球晶界面で破壊したためと考えられ る。しかし、球晶の負の $\mathrm{E}_{\mathrm{BD}}$ は報告值よりも若干大きくな っている。これは細管壁面の木モ空間電荷効果が正の場合 に比べ大きいためと考えられる。

またインパルス及び直流とも正極性の力が負極性よりも 低くなっている。これはトリーの伸展と言う観点で考える と正極性電王を印加した力が負極性の場合よりもトリーか 伸展し易いことを意味している。この結果は穗積氏ら ${ }^{(10)}$ の 交流トリーの伸展は正極性電圧印加時に起こり、インパル ストリーも正極性電压を印加した方が伸展し易いと言う指 摘と定性的に一致している。

\section{5 まとめ}

本論文では模擬トリ一試料を用いて、細管内の放電特性 について娭討を行うと共に、球晶成長させたPPフィルム を模擬トリーの下に固定させた複合絶縁系模擬卜リ一試料 を用いてフィルムの高次構造と紿緣破壊との関係を求めた。 その結果を要約すると以下のようになる。 
（1）模擬トリ一試料における放電特性

（i）直流電圧及びインパルス電圧を印加した場合、細管 の放電電圧は細管長が長くなるに従って上昇し、さらに極 性効果も認められた。またタングステン線一平板電極系に おける架気中の放電電生より常に紃管の放電電圧が高くな った。これは約管壁面にトラップされた染間電荷の影響で あることが示唆された。

（ii）百流電压を印加した場合、綝管の放電電圧は試料 温度の上昇に伴って徐々に低下していくが室温付近で急激 に低下し、60 C付近でほぼ一定になった。これに対しイン パルス電圧を印加した場合、試料温度に対し単調に低下し ていき $60^{\circ} \mathrm{C}$ 付近でほぼ一定となった。これは細管壁面にあ るホモ空間電荷の移動度の温度变化に伴う变化と密接な関 係があるものと推察された。

（2）複合絶縁系模擬トリ一試料における絶縁破壊特性 （i）インパルス電圧を印加した場合、P P ィルムの破 壊孔の位置は細管の固定位置のみによって決定されること、 すなわち細管が球晶界面上にあれば球晶界面で、球晶上にあ れば球晶が破壊することがわかった。一方直流電圧を印加 した場合、細管が球晶界面上に固定されれば球晶界面で破 壊するのに対し、球晶上に固定されると球晶上で点弧した 放電は球晶ラメラに沿って沿面放電し、弱点部分である球 晶界面で破壊した。

（ii）細管が球晶界面上にある場合の絶縁破壊電圧の細管 長依存性及び温度依存性ば印加電圧波形(直流及びインパル ス）によらず、細管の放電電圧とほぼ一致していることか ら、絶縁破壊特性は細管の放電特性によって律則されている ことを明らかにした。

（iii）細管が球晶上にある場合、インパルス絇縁破壊電 圧は細管長及び式料温度によらず細管の放電電圧よりも $1.0 \mathrm{kV}$ 高くなった。一方、直流絶縁破壊電生はインパルス の場合と同様に細管の放電電圧よりも大きくなったが、その 差は細管長の増加及び試料温度の低下と共に大きくなった。 これは球晶上に蓄積したホモ空間電荷の影響であると考え られる。

また、 $60^{\circ} \mathrm{C}$ 以では(2)(i)で述べた破壊痕跡とは異なり、 球晶に複数の微小な破壊孔をもつ痕跡が磼認された。この 破壊痕跡に対応する絶縁破壊電圧は、細管の放電電圧との

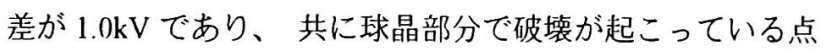
でインパルスの場合と類似していた。さらに、60におい ては二種類の破壊痕跡が確認され、これに対して絶縁破壊 電圧値も二種類が確認された。これらの現象は非常に興味 哚いものであるが、不明な点が多いため、今後検討してい く必要がある。

最後にこの研究は名古屋産業科学研究所による研究助成 と日本高压電気株式会社技術䂤究所より試料を提供して頂 いたことに対し謝意を表します。

(平成 8 年 7 月 24 日受付、平成 8 年 11 月 11 日再受付)
文献

(1):「有機絶縁材料のトリーイングについて」、 電気学会技術報告、No.100（昭和 46 年）

(2):家田他、「現代 高電圧工学」、オーム社

(3): 河村、絢田、家田、電気学会誘電・絶縁材料斫究会 EMI-80-19 (炤和 56 年)

(4):Wagner:Annu .Rep. Cenf. Electr. Insul. Dielectr. Phenome. USA), P62(1978)

(5):山本、水里、長尾、小崎、平成 2 年電気学会全国大会、 338

(6):渡辺、水野、長尾、小崎、平成 5 年電気関係学会東海支 部連合大会、246

(7):K.Kitagawa, G.Sawa, M.Ieda : Japan .J.Appl.Phys. 19, 389 , (1980)

(8):山北、電気学会誘電 · 絶縁材料研究会、EMI-87-71 (昭和 63 年)

(9):神永、福永、第 17 回電気絶縁材料シンポジウム、 VIII-2(1984)

(10)犬石他 誘電体現象論 電気学会編 P.335

(11):穂積、電気学会誘電. 絶縁材料研究会、EMI-88-53 (平成元年)

今 井國治（正員）1963年 2 月 26 日生 1991 年 3 月

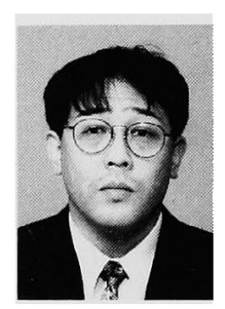
名城大学大学院工学研究科修士課程電気 電子工学専攻修了。1993 年 4 月同大学大 学院博士課程（後期）進学、現在に至る。 高分子材料の放電と絶縁破壊に関する矼 究に従事。

竹内悟 (学生員) 1973 年 3 月 18 日生。1995 年 3

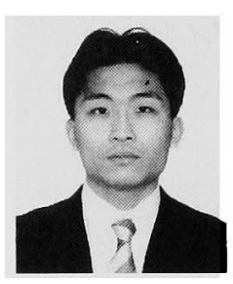
月名城大学理工学部電気電子工学科卒業。 同年 4 月同大学大学院理工学研究科修上 課程電気電子工学専攻入学、現在に至る。 高分子材料の絶縁破壊に関する研究に従 事。

西 山 真 貴 (学生員) 1972 年 3 月 7 日生。1996 年 3 月

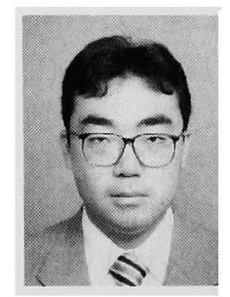
名城大学大学院理工学研究科修士課程電 気電子工学専攻修了。同年 4 月 (株)DENSO に入社、現在に至る。 


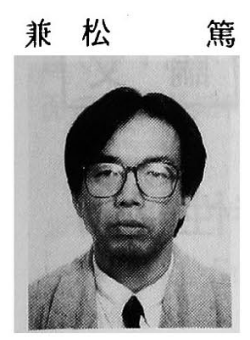

篤（正員）1954 年 8 月 22 日生。1983年 3 月 名古屋大学大学院工学砸究科博上課程(後 期）電気工学専攻淵了。1988 年 3 月か5 1989 年9月までアメリカ合稂国マサチュ 一セッッ工科大学(MIT)高電圧研究所客員 研究員。工学榑上。

綎 IIII IE 人 (正員) 1930作 3 月 30 日生。名城大学、 助手、助教授を経て 1974 年同大学理工学 部教授、1983 年同大学大学院工学研究科 長、1985 年中曅人民共和国招聘教授、1989 年名城大学教務部長、1994 年名城大学付 属高校校長作任、現在に至る。その間、高 電圧工学と電気絶縁工学に関する教育と 研究に従事。1973 年電気学会学術振興賞 (論文賞) を受賞。1974 年工学博士（名 古屋大学）。 